\title{
ADP-Ribosyl Cyclase 1
}

National Cancer Institute

\section{Source}

National Cancer Institute. ADP-Ribosyl Cyclase 1. NCI Thesaurus. Code C84323.

ADP-ribosyl cyclase 1 (300 aa, $\sim 34 \mathrm{kDa}$ ) is encoded by the human CD38 gene. This protein is involved in both ADP-ribose metabolism and signal transduction. 